\title{
REDAKSIONEEL EDITORIAL
}

The festive cover for this volume of Akroterion celebrates half a century of the existence of the journal, originally known as "Newsletter / Nuusbrief". Over the past five decades a great number of classicists - many of them already deceased - have contributed articles, book reviews and didactic material for publication. Without their input it would not have been possible to publish the journal; we therefore dedicate this volume to all these colleagues who, as lovers of the classical world and its heritage, have shared their inexhaustible enthusiasm with our readers over the past fifty years. The hard work of all who have refereed articles with care and helped to ensure the high quality of the journal is also acknowledged with appreciation, as is the work done by previous editors.

Maar dan was daar ook oor die afgelope vyftig jaar 'n groot aantal toegewyde tegniese, sekretariële en administratiewe assistente wat lang ure bestee het aan die tik (nog voor die rekenaar-era!) en redigering van bydraes en ook ander kleiner maar noodwendig belangrike take soos om Akroterion gereed te kry vir die pos. Hulle harde werk word ook met groot waardering erken.

Since Volume 45 (2000) the editorial policy of the journal has slightly changed: Akroterion started to publish articles that would also appeal to members of the general public who share an interest in the Graeco-Roman world. One exciting development was the decision to publish a wider variety of illustrated articles which seem to be so popular that Volume 50 includes two articles on museum artefacts, one from Grahamstown and the other from Stellenbosch. At the same time numismatists also appear to be showing a keen interest.

This volume again includes the winning contribution of the annual essay competition, formerly known as the $B X$ de Wet Essay competition and now renamed the CASA Essay competition. The winning essay for the competition for 2005, "Fate and divine working in Sophocles' Oedipus Rex", was entered by Inge Scheepers of the University of South Africa. Runner-up was Olivier Serrão (University of Rhodes) with "An assessment of Aeneas' status as a hero from a Roman point of view".

Gedurende hierdie ronde van die opstelkompetisie vir voorgraadse studente was daar agt inskrywings wat 'n wye reeks onderwerpe gedek het wat gewissel het van die Griekse tragedie tot regspraak in antieke Egipte. Die inskrywings was almal van 'n hoë gehalte en het getuig van 'n volwasse vermoë om bronne, primêr sowel as sekondêr, te evalueer en te integreer en om 'n skerp fokus op die onderwerp te behou. Dít getuig van die voortreflike werk wat in die relevante departemente aan ons universiteite gedoen word en die kollegas wie se studente hierdie uitstekende opstelle ingeskryf het, verdien almal 'n woord van gelukwensing.

It is our sincere wish that Akroterion will continue to inform and entertain for a long time to come - but in order to reach that goal, we need the continued support and interest of enthusiastic contributors and keen readers!

J C ZIETSMAN

Editor 